\title{
Leaching behavior of major and trace elements from sludge deposits of a French vertical flow constructed wetland
}

\author{
Manon KANIA, Mathieu GAUTIER, Denise BLANC, \\ Maria LUPSEA-TOADER, Laurent MERLOT, Maria- \\ Chiara QUARESIMA, Rémy GOURDON
}

\section{$\rightarrow$ To cite this version:}

Manon Kania, Mathieu Gautier *, Denise Blanc, Maria Lupsea-Toader, Laurent Merlot, Maria-Chiara Quaresima, Rémy Gourdon (2019). Leaching behavior of major and trace elements from sludge deposits of a French vertical flow constructed wetland. Science of The Total Environment, 649, 544-553. doi:10.1016/j.scitotenv.2018.08.364 https://doi.org/10.1016/j.scitotenv.2018.08.364

Please contact the corresponding author (* mathieu.gautier@insa-Iyon.fr) if you are interested by a copy of the article published in the journal. 


\section{Leaching behavior of major and trace elements from sludge deposits of a French vertical flow constructed wetland.}

Kania Manon, Gautier Mathieu*, Blanc Denise, Lupsea-Toader Maria, Merlot Laurent, Quaresima Maria-Chiara, Gourdon Rémy

Univ Lyon, INSA Lyon, DEEP (Déchets Eaux Environnement Pollutions), EA 7429, 69621 Villeurbanne Cedex, France

*Corresponding author: mathieu.gautier@insa-lyon.fr

\section{Graphical abstract}

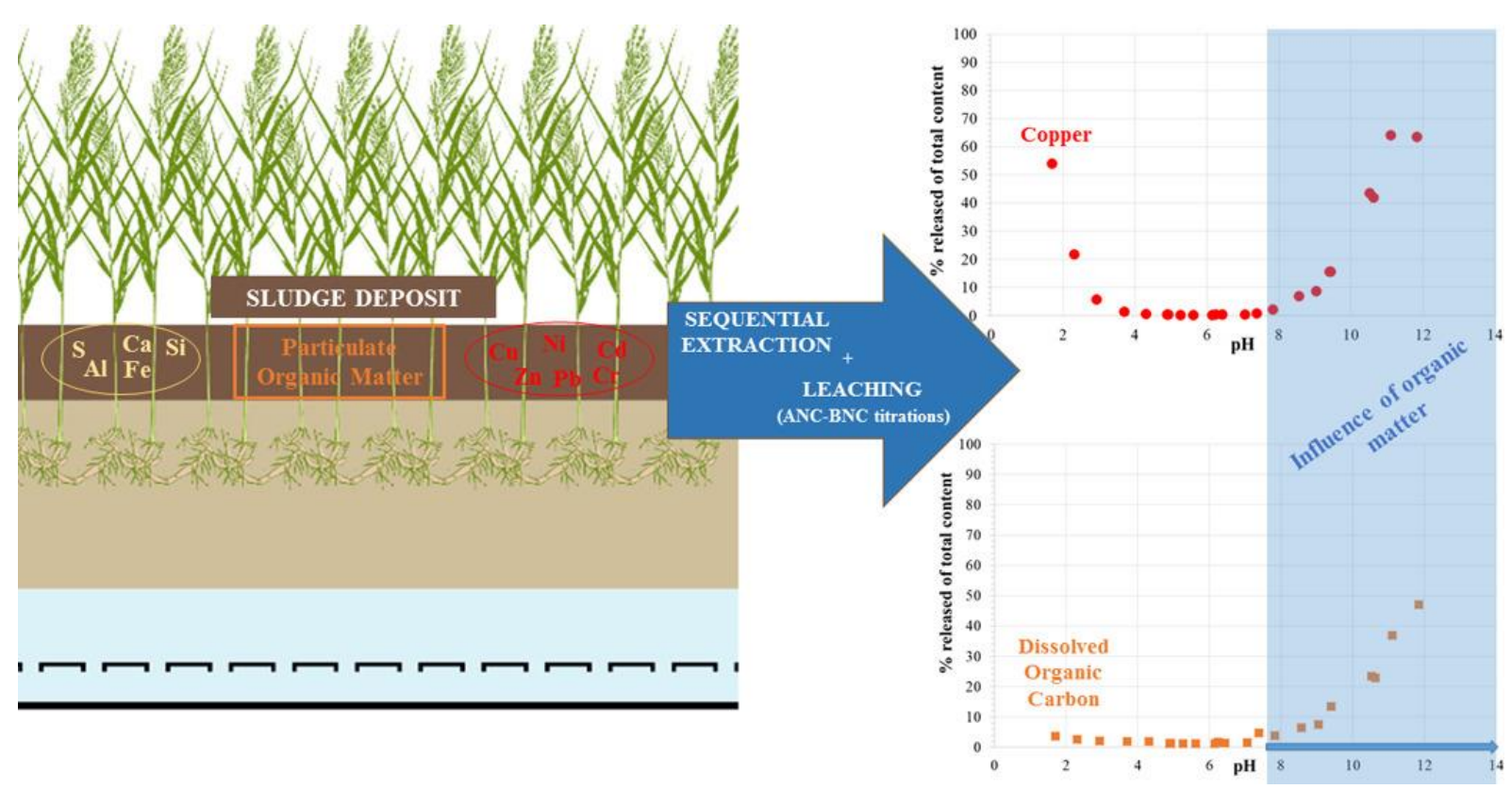

\section{Highlights}

- Leaching of inorganic elements into aqueous solution was very low at neutral pHs.

- The high organic content of the sample influenced the leaching of several trace metals.

- Copper was the trace metal most associated to organic matter in the sample.

- Copper $\mathrm{pH}$-dependent leaching followed the leaching pattern of organic components.

- Leaching of organic compounds and associated trace metals was increased at alkaline pHs. 


\begin{abstract}
Surface sludge deposits were collected from a French Vertical Flow Constructed Wetland (French VFCW) sewage treatment plant. The objectives were to characterize the retention of major elements and trace metals within the sludge deposits particles under regular operating conditions, and the influence of extreme $\mathrm{pH}$ conditions on their potential release which may occur in situations when the plant malfunctions or after land application of the dredged sludge. A sequential extraction protocol was first used to assess the distribution of the elements within the sludge deposits. Results showed that most of $\mathrm{Cu}$ and $\mathrm{Pb}$ were associated to organic matter within the oxidizable fraction. $\mathrm{Zn}, \mathrm{Ni}$ and $\mathrm{Cd}$ were distributed in several fractions, notably bound to Fe-Mn oxides and associated to organic matter. $\mathrm{Cr}$ was analyzed mostly in the residual fraction. Aliquot fractions of sludge deposits were also submitted to Acid and Base Neutralization Capacity tests (ANC-BNC) where the samples were suspended into acidic or alkaline aqueous solutions, and the solutions analyzed after $48 \mathrm{~h}$ contact time. Results showed a $\mathrm{pH}$-dependent leaching profile for all monitored elements. The role of organic matter was observed for almost all metals. It was particularly dominant for $\mathrm{Cu}$ which was leached more extensively under alkaline than acidic conditions. Since $\mathrm{Cu}$ is not an amphoteric element, this leaching pattern was attributed to the leaching of organic matter which followed a same similar $\mathrm{pH}$-dependent profile than $\mathrm{Cu}$. Spectrometric indices were used to characterize soluble organic compounds. Results showed that complex and humified dissolved organic compounds were mostly released under alkaline conditions.
\end{abstract}

\title{
Keywords
}

French Constructed Wetlands; Sludge deposit; Trace elements release; Acid and Basic Neutralization Capacity; Organic matter; Sequential extraction 


\section{Introduction}

Constructed wetlands are considered among the technologies best adapted to domestic wastewater or storm water treatment from small communities. In France, the development of Vertical Flow Constructed Wetlands (VFCWs) has been considerable since the end of the 90s. French VFCWs have proved to be efficient for the treatment of carbon and nitrogen (Kim et al., 2014; Molle et al., 2005; Morvannou et al., 2015). For phosphorus removal, additional treatment stages are necessary to guarantee low level release (Molle et al., 2004 ; Kim et al., 2014). One of the solutions is to precipitate dissolved phosphates by injecting $\mathrm{FeCl}_{3}$ before the percolation of the influent through the filter stages. The precipitates thus formed, mixed with the suspended solids from the influent, progressively accumulate at the surface of the French VFCW in the form of a sludge layer (Chazarenc \& Merlin, 2005; Molle et al., 2004). Several studies have already been published on sludge characteristics and their evolutions in reed bed treatment systems (Caicedo et al., 2015; Matamoros et al., 2012; Nielsen, 2005; Nielsen \& Bruun, 2015). However, there is still a lack of specific studies focused on surface sludge deposits from French VFCWs.

Besides phosphorous and nitrogen issues, a diversity of metallic pollutants are transported in wastewater streams (Vriens et al., 2017) and may accumulate in this layer via (co)-precipitation, complexation or adsorption mechanisms onto particulate organic matter $(\mathrm{OM})$ and/or mineral phases such as clays, Fe-, Mn- or Al-oxides and oxy-hydroxides. These retention mechanisms have positive effects when considering the treatment performance of a French VFCW (Gill et al., 2017). However over the years of operation of the French VFCW, the sludge layer may undergo various biophysicochemical changes $(\mathrm{pH}$; Eh), which may influence the fate of trace metals and/or organic matter (Grybos et al., 2009), leading to potential environmental risks. For example, acidification of the sludge layer may arise from (i) exposure to acidic rainfalls, with $\mathrm{pH}$ reported to range from 4.4 to 5.7 in eastern France (Sanusi et al., 
1996) or 2.89 in some parts of China (Du et al., 2014), (ii) temporary or seasonal contribution of acidic wastewater, or (iii) malfunctioning of the system leading to flooding of the filters and acidogenic biodegradation of organic matter (Kim et al., 2016).

In addition, the thickening of the sludge layer over the years of operation may progressively reduce the permeability of the systems. It is commonly considered that surface sludge layer should be dredged from the filters after 10 to 15 years of operation (Chazarenc \& Merlin, 2005). Dredged sludge may be used for land application, provided the associated potential environmental risks are acceptable. European and French regulations have set threshold limits for trace metals contents $(\mathrm{Cd}, \mathrm{Cr}, \mathrm{Cu}, \mathrm{Hg}, \mathrm{Ni}, \mathrm{Pb}, \mathrm{Zn})$ in sludge and in the receiving soil. Total contents is not however the key factor in the potential environmental risk of trace metals release from sludge. Mobility, which is related to their chemical speciation and the physico-chemical local conditions, has a major influence on their potential release to the water phase (Yang et al., 2014). A proper assessment of the potential risks of sludge deposits in land application should therefore include the evaluation of the potential mobility of the contaminants, and the influence of environmental conditions such as acidity or redox potential on their leaching potential (Chatain et al., 2013; Gonzalez et al., 2017). Although a large number of studies have been published on the subject in the field of solid waste or contaminated soils management, to our knowledge, no specific study has yet been released on the speciation and mobility of inorganic contaminants present in French VFCW sludge deposits.

This study was therefore conducted to experimentally assess the release of major inorganic elements (Al, $\mathrm{Ca}, \mathrm{Fe}, \mathrm{Si}$ and $\mathrm{K})$ and a selection of trace metals $(\mathrm{Cr}, \mathrm{Cu}, \mathrm{Ni}, \mathrm{Zn}, \mathrm{Cd}$ and $\mathrm{Pb}$ ) from surface sludge deposits sampled from a French VFCW sewage treatment plant. The selected plant was already extensively studied by Kim et al. $(2013,2015)$ and Kania et al. (2018a and b, 2019). In this purpose, a methodology was developed based on waste management protocols (Chatain et al., 2013; Gonzalez et al., 2017). Batch pH-dependent 
leaching tests were conducted following acid and base neutralization capacity (ANC-BNC) European standard CENTS/TS 14429, in order to investigate the influence of $\mathrm{pH}$ conditions on the leaching behavior of the material. This method was complemented by sequential extractions of major and trace elements (Chatain et al., 2005; Tessier et al., 1979) to assess their distribution within the sludge deposits mineralogical phases.

\section{Materials and methods}

\subsection{Origin of the sludge deposits sample}

A representative sample of surface deposits was collected from the sludge layer of a full-scale French VFCW sewage treatment plant located in Vercia (France). The plant was being in operation for 8 years at the sampling date. Previous studies described in details the design of the plant and its performance (Kim et al., 2014). The plant was designed and operated according to AZOE-NP ${ }^{\circledR}$ process, which combines an aerobic trickling filter and ferric chloride injection prior to the classical 2 stages of filters. It was designed for 1100 population equivalent and received mostly domestic wastewaters from the Vercia town, and some winery effluents during autumn.

Surface deposits were sampled using a power shovel to extract the entire depth of the sludge layer at 8 spots of the surface of the first filter. The samples were then treated on site to remove gravels and reeds rhizomes manually, mixed and carefully homogenized by quartering with shovels before being transported to the laboratory within no $\geq 3 \mathrm{~h}$. There, an aliquote fraction was freeze-dried and then crushed at $1 \mathrm{~mm}$. The powder obtained was carefully homogenized and stored at $4^{\circ} \mathrm{C}$ until they were used.

Previous studies (Kania et al. 2018a, b, c) conducted on 14 different French VFCW plants, including the one selected here, revealed remarkably similar characteristics of the surface deposits taken from plants of 2-3 years of age and more. This group of samples revealed 
very strong analogies in terms of organic matter composition and physical properties, and was designated as the "mature deposits" typology. The surface deposits sample selected in the present study was representative of this group.

\subsection{Chemical composition}

The Organic matter $(\mathrm{OM})$ content was determined by combustion at $550{ }^{\circ} \mathrm{C}$ until constant mass of a given precise mass of the surface deposits sample (AFNOR - NF EN 15169, 2007). The results was considered to represent the Particulate Organic Matter (POM) since the soluble organic matter was negligible (Kania et al., 2018c). Elemental analyses were performed by alkaline fusion $\left(\mathrm{LiBO}_{2}\right)$ followed by acid digestion $\left(\mathrm{HNO}_{3}\right)$ and subsequent analyses of the solutions by inductively coupled plasma atomic emission spectrometry (ICP-AES) (IRIS Advantage ERS, Thermo Scientific). The following elements were analyzed : silicon (Si), aluminum $(\mathrm{Al})$, iron $(\mathrm{Fe})$, manganese $(\mathrm{Mn})$, magnesium $(\mathrm{Mg})$, calcium $(\mathrm{Ca})$, sodium $(\mathrm{Na})$, potassium (K), titanium (Ti) and phosphorus $(\mathrm{P})$. Other trace metals (chromium $(\mathrm{Cr})$, copper $(\mathrm{Cu})$, nickel $(\mathrm{Ni})$, zinc $(\mathrm{Zn})$, cadmium $(\mathrm{Cd})$ and lead $(\mathrm{Pb}))$ were analyzed using a Sciex Perkin Elmer ELAN 5000a. ICP-mass spectrometer.

Carbon and sulfur contents were determined with a HORIBA EMIA 320V2 analyzer. 1 $\mathrm{g}$ of dry powdered samples was calcined at $1400{ }^{\circ} \mathrm{C}$ under a flow of $\mathrm{O}_{2}$, followed by quantification of carbon and sulfur oxides by infrared absorption.

\subsection{Sequential chemical extraction}

A sequential chemical extraction protocol adapted from Chatain et al. (2005) and Tessier et al. (1979) was carried out in triplicates to determine the distribution of metals in the sludge, with respect to five fractions, namely: (F1) exchangeable fraction, (F2) extractible fraction bound to carbonates, (F3) reducible fraction (bound to Fe-Mn oxides), (F4) oxidizable fraction (bound to organic matter), (F5) and residual fraction. The so-called "reducible" and "oxidizable" 
fractions corresponded to phases that can be dissolved respectively by reduction (oxides and oxi-hydroxides) or oxidation (sulfides or organic matter). A dry mass of $1 \mathrm{~g}$ of sample was extracted in 5 successive stages according to the following protocol:

- Exchangeable fraction F1: extraction at room temperature for $1 \mathrm{~h}$ with $8 \mathrm{~mL}$ of a molar magnesium chloride solution ( $1 \mathrm{M} \mathrm{MgCl}, \mathrm{pH} 7)$ under continuous agitation;

- Extractible fraction F2 (bound to carbonates): extraction with $8 \mathrm{~mL}$ of $1 \mathrm{M} \mathrm{NaOAc}$ solution adjusted to $\mathrm{pH} 5$ with acetic acid (HOAc), under continuous agitation;

- Reducible fraction F3 (bound to Fe-Mn oxides): extraction with $20 \mathrm{~mL}$ of $0.04 \mathrm{M}$ $\mathrm{NH}_{2} \mathrm{OH} . \mathrm{HCl}$ (hydroxylamine hydrochloride solution), in $25 \%$ (v/v) HOAc, performed at $96 \pm 3{ }^{\circ} \mathrm{C}$ with occasional agitation and for the time needed for complete dissolution of the free iron oxides;

- Oxidizable fraction F4 (bound to organic matter): the solid residue collected from the previous step was mixed with $3 \mathrm{~mL}$ of $0.02 \mathrm{M} \mathrm{HNO}_{3}$ and $5 \mathrm{~mL}$ of $30 \% \mathrm{H}_{2} \mathrm{O}_{2}$ adjusted to $\mathrm{pH} 2$ with $\mathrm{HNO}_{3}$, and the mixture was heated at $85 \pm 2{ }^{\circ} \mathrm{C}$ for $2 \mathrm{~h}$ with occasional agitation. A second $3 \mathrm{~mL}$ aliquot of $30 \% \mathrm{H}_{2} \mathrm{O}_{2}$, adjusted to $\mathrm{pH} 2$ with $\mathrm{HNO}_{3}$, was then added and the sample was heated again at $85 \pm 2{ }^{\circ} \mathrm{C}$ for $3 \mathrm{~h}$ with intermittent agitation. After cooling, $5 \mathrm{~mL}$ of $3.2 \mathrm{M} \mathrm{NH}_{4} \mathrm{OAc}$ in $20 \%$ (v/v) $\mathrm{HNO}_{3}$ was added and the sample was diluted to $20 \mathrm{~mL}$ and agitated continuously for $30 \mathrm{~min}$. The addition of $\mathrm{NH}_{4} \mathrm{OAc}$ is designed to prevent adsorption of extracted metals onto the oxidized sample.

- Residual fraction F5: this fraction was calculated as the difference between the cumulated extracted fractions and the total content of each element.

Between each successive extraction, the suspensions were centrifuged at $10000 \mathrm{rpm}$ for $30 \mathrm{~min}$. After filtration at $0.45 \mu \mathrm{m}$, the supernatant was analyzed for trace elements, and the residue was further washed with $20 \mathrm{~mL}$ of deionized water and centrifuged for $30 \mathrm{~min}$. Then the solid residue was further extracted with $20 \mathrm{~mL}$ of water, whereas the supernatant was 
discarded. Major and minor and trace elements were then analyzed in the respective solutions by ICP-AES (Ultima 2; Horiba Jobin Yvon SAS).

\subsection{Experimental leaching protocol}

The ANC-BNC leaching protocol was based on the CENTS/TS 14429 European standard, which is used in the domain of waste management. $5 \mathrm{~g}$ of dry sludge deposits sample and $50 \mathrm{~mL}$ of leachant (liquid-to-solid ratio $=10 \mathrm{~g} / \mathrm{mL}$ ) were mixed in a $250 \mathrm{~mL}$ centrifuge tube (polypropylene copolymer, Nalgene ${ }^{\circledR}$ ). All assays were triplicated. The following aqueous leachants were used to evaluate the effect of $\mathrm{pH}$ on the leaching behavior:

- deionized water,

- aqueous solutions of hydrochloric acid at different concentrations,

- aqueous solutions of potassium hydroxide at different concentrations.

Blanks were also carried out in triplicates under the same conditions as the assays, but without the addition of sample. All the tubes (tests and blanks) were placed for $48 \mathrm{~h}$ in a rotary shaker set at a speed of $9 \mathrm{rpm}$. The contact time was defined according to the European standard (CENTS/TS 14429) and already used for ANC-BNC test conducted on sediment with high content of OM (Chatain et al., 2013). pH was then measured in all suspensions, and the tubes were centrifuged at $10000 \mathrm{rpm}$ for $10 \mathrm{~min}$. The supernatants were filtered at $0.45 \mu \mathrm{m}$ through Sartorius cellulose acetate filters and stored at $4{ }^{\circ} \mathrm{C}$ before analyses. The remaining sludge material was collected from each tube, freeze-dried and stored at $4{ }^{\circ} \mathrm{C}$ for further analyses.

\subsection{Leachates analyses}

The leachates were analyzed for Dissolved Total Carbon (DTC) and Dissolved Inorganic Carbon (DIC) using a Shimadzu 505A Carbon analyzer. Dissolved Organic Carbon (DOC) was calculated as the difference between DTC and DIC. Total concentration of major $(\mathrm{Al}, \mathrm{Ca}, \mathrm{Fe}, \mathrm{Si}$ and $\mathrm{K})$ and trace elements $(\mathrm{Cr}, \mathrm{Cu}, \mathrm{Ni}, \mathrm{Zn}, \mathrm{Cd}$ and $\mathrm{Pb}$ ) were measured in the 
solutions by ICP-AES (Ultima 2; Horiba Jobin Yvon SAS). Orthophosphate $\left(\mathrm{PO}_{4}{ }^{3-}\right)$ ions were analyzed by ion chromatography (Dionex, Model C25).

Ultraviolet-visible (UV-VIS) absorbances were measured at 254, 465, $665 \mathrm{~nm}$ using a Shimadzu UV-2450 spectrophotometer. SUVA (specific ultraviolet absorbance) and $\mathrm{A}_{1}$ indexes were then calculated according to Eqs. (1)-(2).

$$
\begin{aligned}
& \text { SUVA }=\frac{\mathrm{A}_{254}}{\text { DOC concentration }} \\
& \mathrm{A}_{1}=\frac{\mathrm{A}_{465}}{\mathrm{~A}_{665}}
\end{aligned}
$$

SUVA index was considered as an indicator of the humification of the dissolved organic compounds based on its correlation with the degree of aromaticity (Weishaar et al., 2003), according to Eq. (3):

$$
\text { Aromaticity }=6.52 \mathrm{SUVA}+3.63
$$

$A_{1}$ was proposed as a humification index (Orlov, 1986). Both humic and fulvic substances absorb at $465 \mathrm{~nm}$, whereas only the more condensed humic substances absorb at 665 nm (Rutkowska \& Pikuła, 2013). It is usually considered that $\mathrm{A}_{1}$ ratios below 5 are characteristics of humified samples (Zbytniewski \& Buszewski, 2005).

\section{Results and discussion}

\subsection{Composition of sludge deposits}

The elemental composition of the sludge deposit is shown in Table 1. The material was predominantly organic with a POM content of $62.0 \pm 2.5 \% \mathrm{w} / \mathrm{w}$ dry matter (DM). Silicon, calcium and iron contents were found to be the major inorganic elements, at concentrations of 5.7, 3.8 and $3.5 \%$ w/w DM respectively. The high iron content was attributed to the implementation of ferric chloride injection on the treatment plant, used to remove phosphorus. 
Contents in trace metals $\mathrm{Zn}, \mathrm{Cu}, \mathrm{Pb}, \mathrm{Cr}, \mathrm{Ni}$ and $\mathrm{Cd}$ were respectively $1219,623,64.2$, $57.4,30.5$ and $1.7 \mathrm{mg} / \mathrm{kg}$ of DM. These concentrations were all below the French regulatory limits for sludge application on agricultural lands. Except for $\mathrm{Cu}$ which was analyzed at higher concentrations here, very similar contents in trace metals were reported in sludge from reed bed systems (Caicedo et al., 2015; Matamoros et al., 2012; Nielsen \& Bruun, 2015). The trace metals contents were also similar to the concentrations classically reported in activated sludge, ranging from 1 to $10 \mathrm{mg} / \mathrm{kg}$ of $\mathrm{DM}$ for $\mathrm{Cd}, 10-100$ for $\mathrm{Cr}$, $\mathrm{Ni}$ and $\mathrm{Pb}$, and $100-1000$ for $\mathrm{Zn}$ and $\mathrm{Cu}$ (Lachassagne, 2015). The relatively high contents in $\mathrm{Zn}$ and $\mathrm{Cu}$ observed here may be attributed to anthropic origins such as leaching of roof construction materials for zinc and grape crops pesticide treatment for copper.

Table 1 Organic Matter $(\mathrm{OM})$ content and elemental composition of sludge deposit sample.

\begin{tabular}{cc|cc}
\hline $\begin{array}{c}\text { OM and } \\
\text { major elements }\end{array}$ & $\begin{array}{c}\text { Concentrations } \\
(\text { \% w/w DM) }\end{array}$ & Trace metals & $\begin{array}{c}\text { Concentrations } \\
(\mathbf{m g} / \mathbf{k g} \mathbf{~ D M})\end{array}$ \\
\hline $\mathrm{OM}$ & 62.0 & $\mathrm{Zn}$ & 1219 \\
\hline $\mathrm{C}_{\mathrm{Tot}}$ & 33.0 & $\mathrm{Cu}$ & 623 \\
\hline $\mathrm{N}_{\mathrm{Tot}}$ & 3.0 & $\mathrm{~Pb}$ & 64.2 \\
\hline $\mathrm{S}_{\mathrm{Tot}}$ & 0.7 & $\mathrm{Cr}$ & 57.4 \\
\hline $\mathrm{Si}$ & 5.7 & $\mathrm{Ni}$ & 30.5 \\
\hline $\mathrm{Ca}$ & 3.8 & $\mathrm{Cd}$ & \\
\hline $\mathrm{Fe}$ & 3.5 & & \\
\hline $\mathrm{P}$ & 2.0 & & \\
\hline $\mathrm{Al}$ & 2.1 & & \\
\hline $\mathrm{K}$ & 0.4 & & \\
\hline $\mathrm{Mg}$ & 0.3 & & \\
\hline $\mathrm{Ti}$ & & & \\
\hline $\mathrm{Na}$ & 0.2 & & \\
\hline
\end{tabular}

\subsection{Distribution of major and trace elements}

The results from the sequential extractions are shown in Fig.1. The major elements Si, $\mathrm{Al}$ and to a smaller extent $\mathrm{Fe}$ were found to be predominantly associated to the residual fraction (from 59 to $98 \mathrm{w} / \mathrm{w} \%$ of DM). This observation indicated that these elements were present mostly as constituents of stable mineral phases, thereby suggesting their low mobility. S was mostly associated to the oxidizable fraction whereas $\mathrm{Ca}$ was more evenly distributed in the 
different fractions. $\mathrm{Si}, \mathrm{Al}, \mathrm{Fe}$ and $\mathrm{S}$ were almost not present in the exchangeable fraction $(\mathrm{F} 1)$, except $\mathrm{Ca}$, probably in the form of calcite. Fe was significantly present in the oxidizable fraction F4 (34 w/w \% of DM), probably because of the flocculation of soluble or colloidal organic constituents by $\mathrm{FeCl}_{3}$ used to precipitate phosphates. The presence of calcite in the same surface deposits sample was already shown (Kim et al., 2013) and in waste materials with lower organic contents, such as bottom ash or soils (Gonzalez et al., 2017; Samourgiannidis \& Matsi, 2013).

(a)

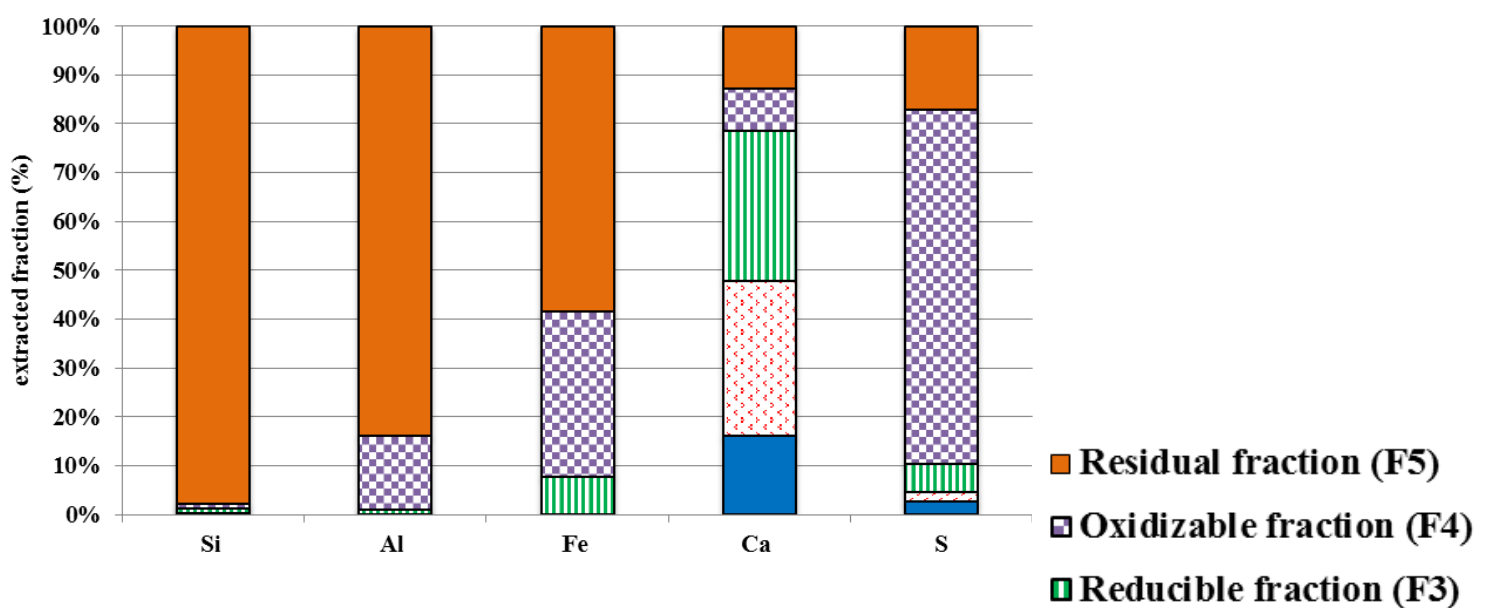

(b)

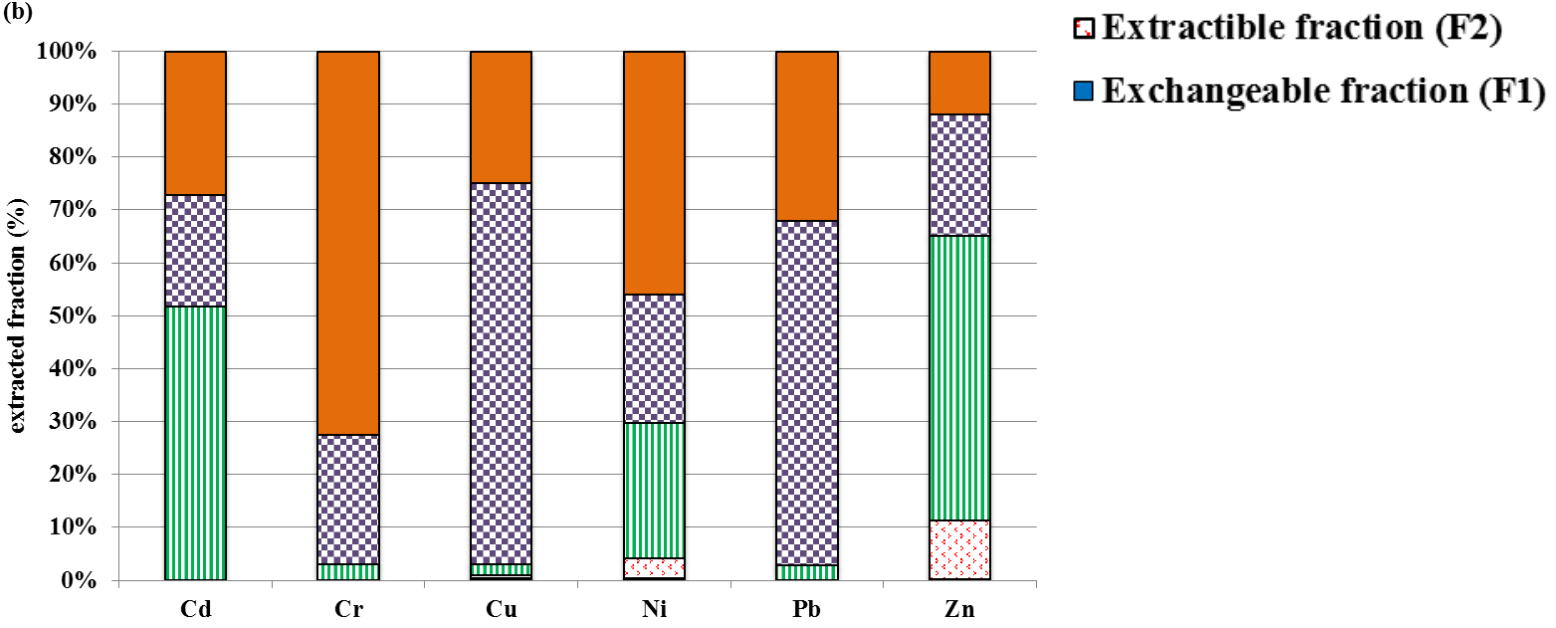

Fig.1. Distribution of (a) major elements and (b) trace elements in sludge deposits as evaluated by sequential chemical extraction.

The results obtained for trace elements distribution are shown in Fig. 1.b. Regarding Cd, it can be seen that $52 \%$ were associated to Fe-Mn oxides, $21 \%$ to the oxidizable fraction, suggesting possible association to organic matter (Bruland, 1992), and 27\% to the residual fraction. Cr was mostly associated to the residual fraction (72\%) and to a lesser extent to the 
oxidizable fraction (25\%), probably associated to organic matter. $\mathrm{Cr}(\mathrm{VI})$ is known to be easily reduced to $\mathrm{Cr}$ (III) by OM (Di Luca et al., 2011). Therefore Cr(III), which is less soluble than $\mathrm{Cr}(\mathrm{VI})$, was probably largely predominant due to the high OM content in sludge deposits. The association of chromium with organic matter has already been reported in organic material such as tannery sludge (Chen et al., 2015). On the contrary in mineral materials, $\mathrm{Cr}$ was reported to be mainly associated to the residual fraction, as reported in bottom ash (Gonzalez et al., 2017).

$\mathrm{Cu}$ and $\mathrm{Pb}$ were found mainly within the oxidizable fraction (72 and 65\% respectively), probably sorbed to organic matter. The observed high affinity of these elements with OM confirmed previous studies on harbor sediment (Chatain et al., 2013) and activated sludges (Fuentes et al., 2004). The formation of stable complexes between copper and organic ligands was reported by several authors (Da Silva et al., 2002; Lu \& Allen, 2001). Most of the remaining copper and lead was found in the residual fraction (24\% and $32 \%$, respectively) suggesting an association to stable mineral phases such as calco-alumino-silicate phases (Fuentes et al., 2004; Gonzalez et al., 2017).

$\mathrm{Ni}$ and $\mathrm{Zn}$ were distributed in all the fractions except F1 (exchangeable fraction). Almost $50 \%$ of Ni total content was found in the residual fraction, as already reported in activated sludge by Fuentes et al. (2004). The rest of Ni content was equally associated to organic matter (26\%) and Fe-Mn oxides (24\%), as already reported by Jenne (1968) in soils. Previous studies by other authors reported $\mathrm{Zn}$ predominance in the carbonates-bound fraction in sediments, activated sludges or bottom ash (Di Luca et al., 2011 ; Fuentes et al., 2004 ; Gonzalez et al., 2017).

The results were very consistent with the partitioning of these metals in the sediments from a constructed wetland treating rainfall runoff from a motorway (Gill et al., 2017). However, in comparison to these sediments, the trace metals in sludge deposit from French VFCW treating domestic wastewater were observed to be less associated with Fe-Mn oxides and more 
associated with organic matter. Wiśniowska and Włodarczyk-Makuła (2018) recently reported data on the distribution of $\mathrm{Pb}, \mathrm{Cd}$ and $\mathrm{Ni}$ in digested sewage sludges. They distinguished mobile (fractions 1 and 2) and not mobile fractions (fractions 3, 4 and 5). The mobile forms of $\mathrm{Pb}, \mathrm{Cd}$ and $\mathrm{Ni}$ in sludge deposit from constructed wetlands were found in much smaller quantity $(\leq 4 \%)$ than in digested sewage sludge (in the range $25-42 \%$ ).

\subsection{Leaching behavior of the sludge deposits and $\mathrm{pH}$ effect}

\subsubsection{Sludge deposits buffering capacity}

Fig. 2 shows the $\mathrm{pH}$ variation of sludge deposits suspensions in de-ionized water spiked with concentrated acidic (positive scale) or alkaline (negative scale) aqueous solutions. Results obtained in water alone showed that the "natural" $\mathrm{pH}$ was 6.4. The set of experimental tests altogether revealed a low alkaline or acidic neutralization capacity of the sludge deposits, with $\mathrm{BNCpH} 12=-3.5 \mathrm{~mol} \mathrm{eq} / \mathrm{kg}$ and $\mathrm{ANCpH} 2=3.5 \mathrm{~mol} \mathrm{eq} / \mathrm{kg}$. A different behavior was reported for more inorganic materials with higher carbonates contents. For example, Chatain et al. (2013) reported on marine sediments a high $\mathrm{ANCpH} 2=7.5 \mathrm{~mol}$ eq $/ \mathrm{kg}$ with a strong buffering capacity at $\mathrm{pH}$ 6.0, due to the dissolution of carbonate compounds. More generally, mineral materials such as ashes (Chen et al., 2010 ; Gonzalez et al., 2017) or cementitious materials (Peyronnard et al., 2009) were reported to exhibit one or several strong buffering capacities along the $\mathrm{pH}$ scale. 


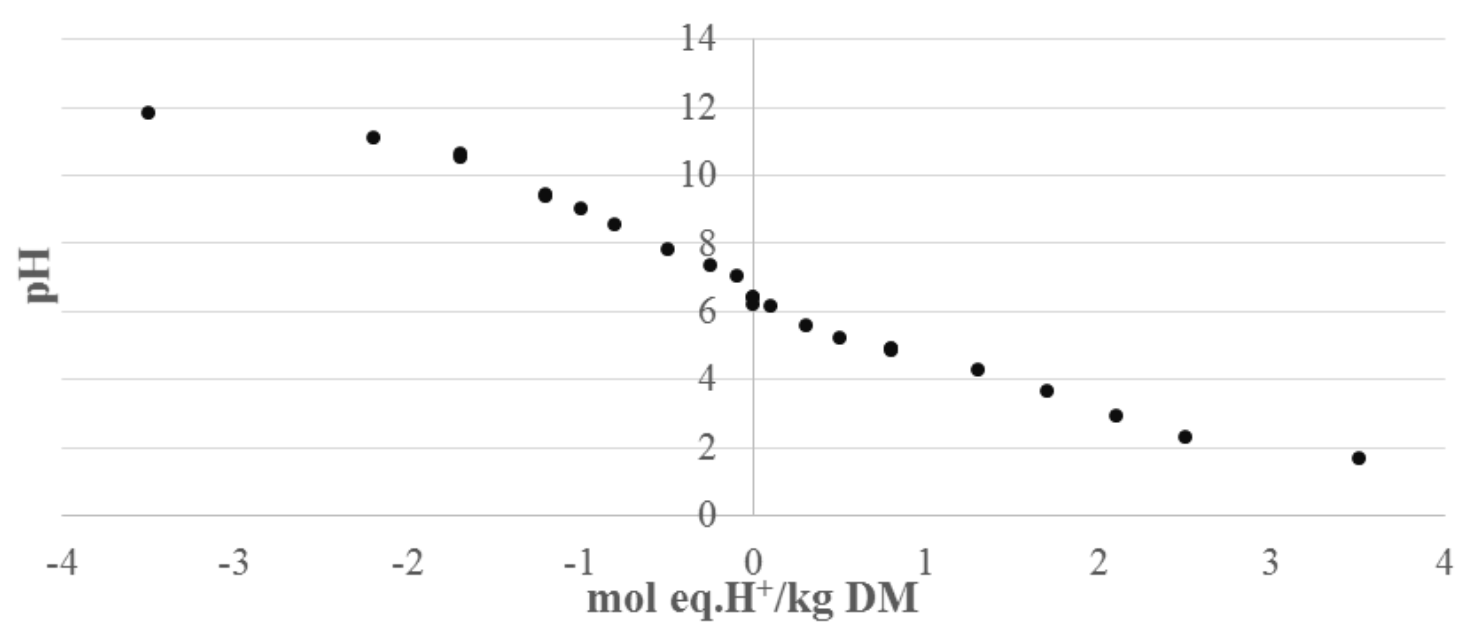

Fig. 2. Acid / alkaline titration curve of the sludge deposits sample.

The low alkaline and acidic neutralization capacity observed for the sludge deposits sample studied here was attributed to their high organic content $(62.0 \%$, Table 1$)$. Similar observations were reported by other authors for organic sediments or soil (Fang et al., 2016; Martin-Torre et al., 2015).

\subsubsection{Leaching of major elements}

Figs. 3 and 4 plot the concentrations of the different elements analyzed in the leachates as a function of $\mathrm{pH}$. The observed release was controlled by several processes, notably: (i) the form and distribution of the considered element within the sludge particles, (ii) the accessibility and solubility of the respective bearing phases and their sensitivity to $\mathrm{pH}$, (iii) the solubility of the considered element depending upon the $\mathrm{pH}$ and ionic composition of the aqueous phase. 

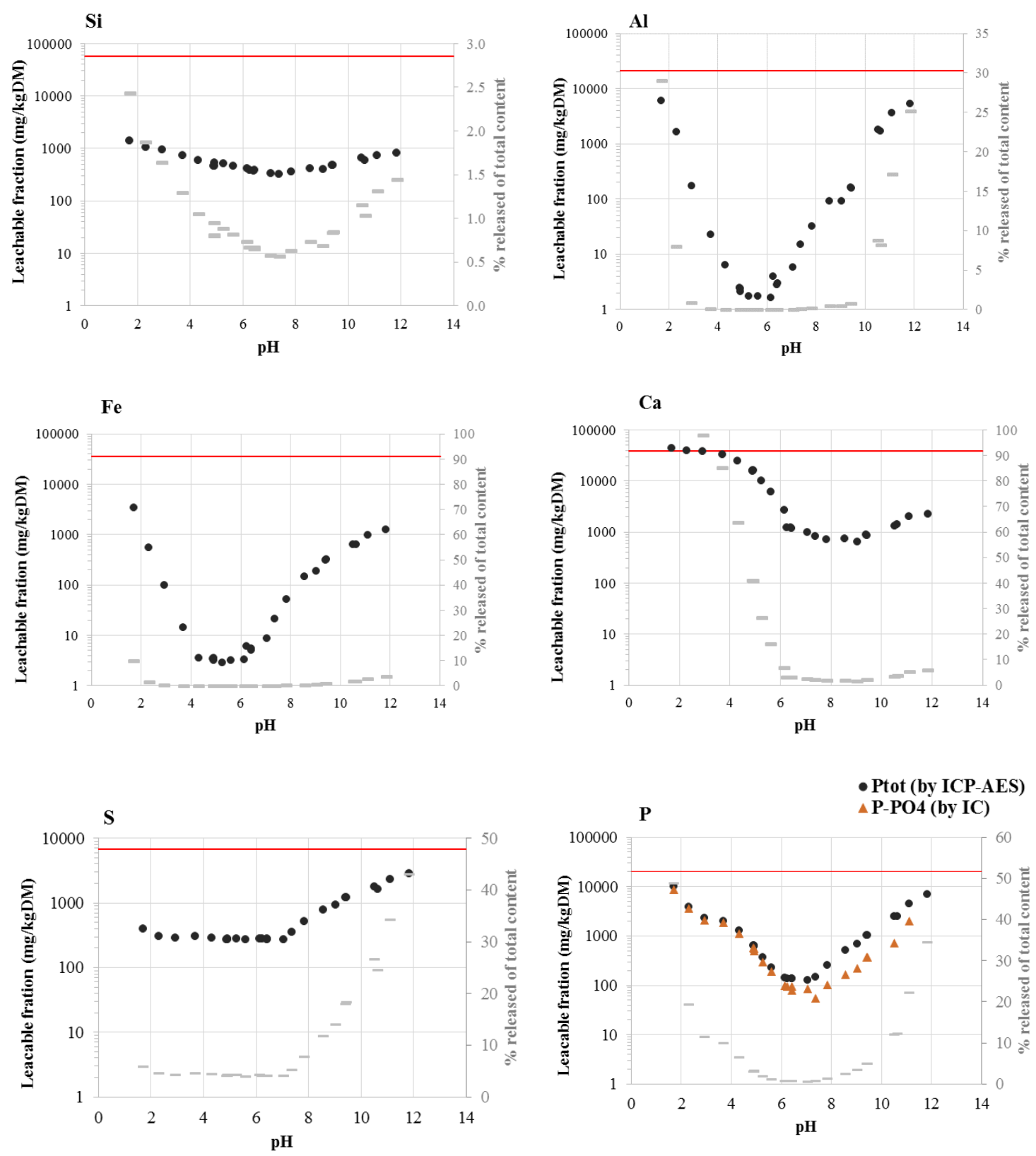

- Leachable fraction (mg/kgDM) — Total content $(\mathrm{mg} / \mathrm{kgDM}) \quad---\mathrm{QL} \quad-\quad \%$ released of total content

Fig. 3. Leaching of major elements and $S$ and $P$ from sludge deposits sample at equilibrium with water at room temperature and different $\mathrm{pH}$ values. The leached fraction (black dots) and total contents (red lines) are related to the left axis of the graphs. The axis on the right side of the graphs is related to the grey dashes showing the results as \% released of total content.

Fig. 3 shows that $\mathrm{Al}$ and Fe leaching behaviors were very similar, following an inversed bell-shaped curve typical of their amphoteric properties. Their release was very low between pH 4 and $7(<0.02 \%)$ and increased at higher and lower $\mathrm{pH}$, in good agreement with their 
association to the residual fraction discussed above. In a similar manner, $\mathrm{Si}$, which has also shown to be mostly associated to the residual fraction such as silicate, was solubilized marginally (less than $2 \%$ of its total content) and almost regardless of $\mathrm{pH}$. Ca leaching was also low and relatively independent from $\mathrm{pH}$ between $\mathrm{pH} 6$ and 10. Leaching slightly increased at $\mathrm{pH}$ above 10 whereas a much stronger increase was observed at $\mathrm{pH}$ below 6 , reaching close to $100 \%$ of release. This observation, combined with the results from fractionation discussed above, which showed that $\mathrm{Ca}$ was predominantly associated with carbonates in fraction $\mathrm{F} 2$, suggested that the dissolution of calcite was the key mechanism controlling the leaching of Ca. The complete dissolution of calcite under acidic conditions was already reported by other authors (Drapeau et al., 2017). On the contrary, a higher fraction of sulfur was leached under alkaline condition (maximum release of $43 \%$ ). Other published studies dealing with the leaching behavior of mineral waste such as bottom ash from municipal solid waste incineration on the contrary reported no leaching of sulfates at alkaline pH (Gonzalez et al., 2014). The different behavior observed here may therefore be attributed to the high organic contents of sludge deposits although further investigations would be needed to elucidate the mechanisms.

The leaching profiles of total phosphorus $\left(\mathrm{P}_{\mathrm{Tot}}\right)$ and orthophosphate ions $\left(\mathrm{PO}_{4}{ }^{3-}\right)$ followed an inversed bell curve as observed for $\mathrm{Al}$ and $\mathrm{Fe}$. Leaching was minimal between $\mathrm{pH}$ 6 and 8 and increased under more acidic or alkaline conditions, reaching releases close to $34 \%$ of phosphorus total content at $\mathrm{pH} 11.8$ and above $49 \%$ at $\mathrm{pH} 1.5$. Under acidic conditions, it was observed (Fig. 3) that the leaching of $\mathrm{P}_{\text {Tot }}$ and $\mathrm{PO}_{4}{ }^{3-}$ were similar, indicating that $\mathrm{PO}_{4}{ }^{3-}$ was the dominant phosphorus species in solution. Under alkaline conditions, the leachates contained more $\mathrm{P}_{\mathrm{Tot}}$ than orthophosphates, highlighting the presence of one or several other form(s) of phosphorus such as organic phosphorus. In previous studies conducted on sludge deposits sampled from the same wetland, Kim et al (2016) showed that under alkaline conditions, 
phosphorus was predominantly leached as inorganic forms bound mainly to Fe and to a smaller extend to $\mathrm{Ca}$ and $\mathrm{Al}$.

\subsubsection{Leaching of trace metals}

Fig. 4 shows the results obtained for the leaching of trace metals versus $\mathrm{pH}$. In most cases, leaching was very low around neutrality but increased drastically under more acidic $\mathrm{pH}$, and for some elements also under alkaline conditions. Among the selected trace metals, Zn was present at the highest concentration in the sludge deposit sample. Its inversed bell-shaped $\mathrm{pH}-$ dependent leaching curve was in agreement with its amphoteric properties. The fractions of $\mathrm{Zn}$ total content leached under either acidic or alkaline conditions were very high (close to 100\% at $\mathrm{pH}$ 1.5). Based on the results from fractionation tests (Fig. 1.b), the leaching of Zn under acidic conditions was explained by the dissolution of carbonates. However, other mechanisms were possible. McBride et al. (1979) suggested that $\mathrm{Zn}$ release under acidic $\mathrm{pH}$ would be also affected by the fraction of $\mathrm{Zn}$ sorbed onto $\mathrm{Fe}$ or $\mathrm{Al}$ oxides. 

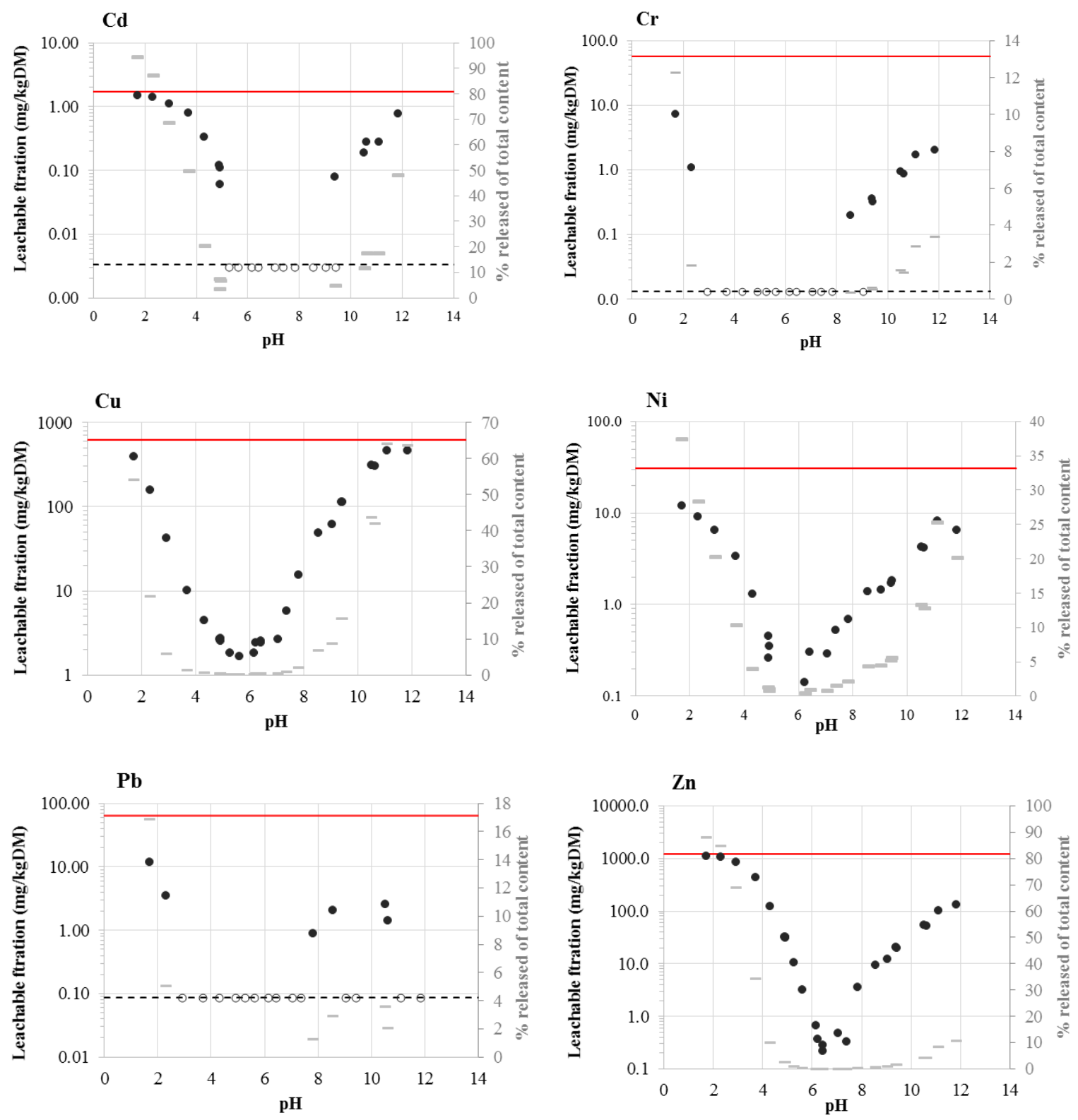

- Leachable fraction (mg/kgDM) — Total content $(\mathrm{mg} / \mathrm{kgDM}) \quad---\mathrm{QL} \quad-\quad \%$ released of total content

Fig. 4. Leaching of target trace elements from sludge deposits sample at equilibrium with water at room temperature and different $\mathrm{pH}$ values. The leached fraction (black dots) and total contents (red lines) are related to the left axis of the graphs. The axis on the right side of the graphs is related to the grey dashes showing the results as \% released of total content.

$\mathrm{Cr}, \mathrm{Ni}$ and $\mathrm{Cd}$ were present in the sludge deposits at much lower concentrations than $\mathrm{Zn}$, and were therefore released at lower concentrations into the aqueous solutions. Cr leaching was below its analytical limit of quantification between $\mathrm{pH} 3$ and 8 . It was released in more significant quantities under more acidic or more alkaline conditions, in agreement with its amphoteric properties. However the fraction of $\mathrm{Cr}$ leached remained low as compared to the 
other trace metals (around 12\% of its total content at $\mathrm{pH} 1.5$ and 3\% at $\mathrm{pH} 11.8$ ), which was attributed to its association to the stable residual fraction, as mentioned above (Fig. 1.b). Cd and Ni showed very similar profiles with a bell-shaped $\mathrm{pH}$-dependent leaching curve. This observation was surprising since unlike $\mathrm{Al}, \mathrm{Fe}$ and $\mathrm{Zn}$ discussed above, $\mathrm{Cd}$ and $\mathrm{Ni}$ are not known to exhibit amphoteric properties. They were therefore not expected to leach significantly under alkaline conditions. Fig. 1 showed however that a high proportion of $\mathrm{Cd}$ (ca. 50\%), and to a smaller extend $\mathrm{Ni}$ (ca. 20\%), was associated to Fe-Mn oxides (fraction F3) in the sludge deposit sample. Sequential extractions showed that about $20 \%$ of both $\mathrm{Cd}$ and $\mathrm{Ni}$ were also associated to the oxidizable fraction (organic matter). The strong leaching of $\mathrm{Cd}$ and high $\mathrm{pH}$ values may therefore be explained by several mechanisms such as their desorption from Fe-Mn oxides, the dissolution of the Fe-oxides bearing phases, and the leaching of organic ligands from the particulate organic matter.

In a similar manner, Fig. 4 showed that $\mathrm{Cu}$, although not amphoteric either, was leached more extensively under alkaline conditions, with close to $64 \%$ of its total content leached at $\mathrm{pH}$ 11.8. vs $54.0 \%$ at $\mathrm{pH} 1.5$. Since the fractionation results showed that around $80 \%$ of $\mathrm{Cu}$ total content was associated to OM (Fig. 1.b), this observation was attributed to the affinity of copper to $\mathrm{OM}$ as will be discussed in the following section. Finally $\mathrm{Pb}$ was also highly associated to $\mathrm{OM}$ as shown in Fig. 1.b, but its concentration was low and therefore its concentration in the leachates were close to the limits of solubilities.

\subsection{Influence of organic matter on trace metals leaching from sludge deposits}

\subsubsection{Leaching behavior of organic matter}

Fig. 5.a shows the release of dissolved total carbon (DTC) and dissolved organic carbon (DOC) vs. pH. Almost all carbon measured in the leachates was organic. DOC leaching observed at natural $\mathrm{pH}(6.4)$ was less than $4 \%$ of the total content in organic carbon. Decreasing 
$\mathrm{pH}$ had little effect on DOC release. On the contrary, alkaline conditions showed a strong increase in DOC release. Up to around 50\% of the dissolved organic carbon was leached at $\mathrm{pH}$ 11.8. Under these very alkaline conditions, dissolved inorganic carbon was measured at relatively small concentrations in the leachates. Biopolymers such as lignin, humic and fulvic acids are known to be partially hydrolyzed or solubilized under alkaline conditions (Grybos et al., 2009). The observed release of DOC may therefore be explained by these phenomena affecting the particulate organic matter (POM) in contact with aqueous alkaline solutions (Mikutta et al., 2005).

(a)

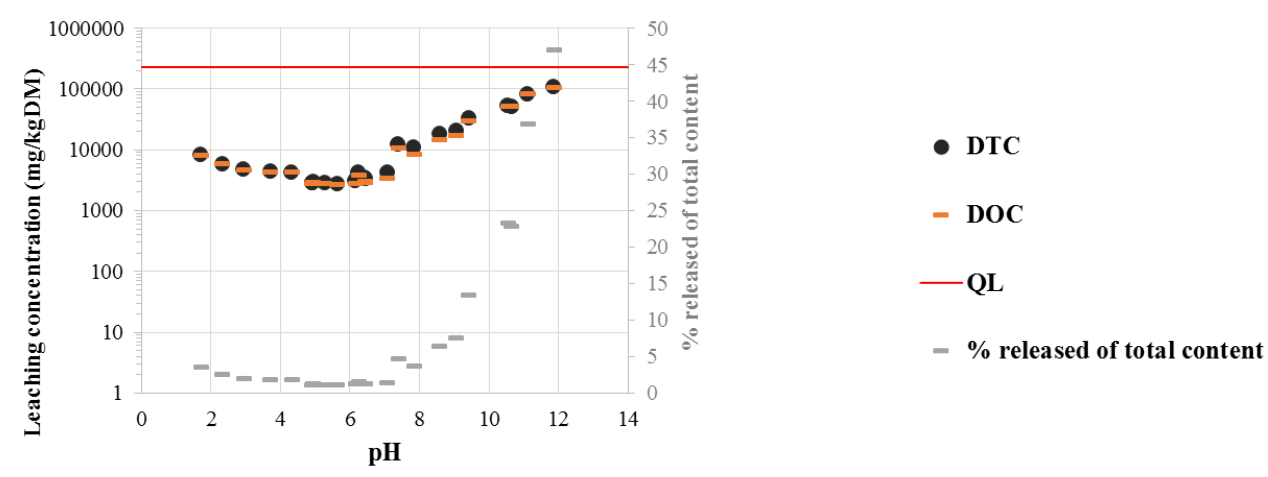

(b)

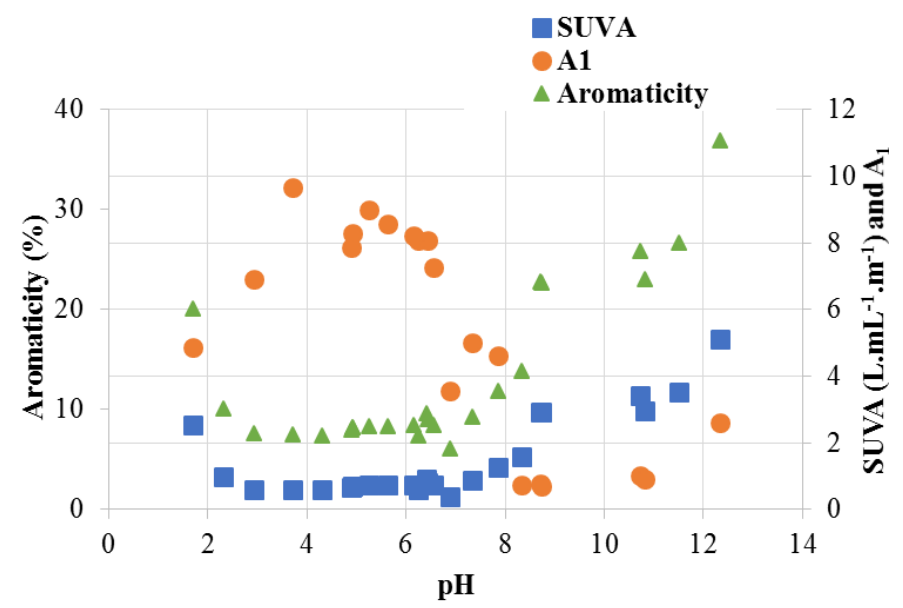

Fig. 5. Leaching of organic matter from sludge deposit sample at equilibrium with water at room temperature and different $\mathrm{pH}$ values. $\mathrm{L} / \mathrm{S}$ ratio $=10 \mathrm{~L} / \mathrm{kg}$; contact time: $48 \mathrm{~h}$ (a) cumulated release of dissolved total and organic carbon and (b) $\mathrm{A}_{1}\left(\mathrm{~A}_{465} / \mathrm{A}_{665}\right)$ index of dissolved organics; SUVA (L.mg ${ }^{-}$ $\left.{ }^{1} \cdot \mathrm{m}^{-1}\right)$ and aromaticity of dissolved organics. 


\subsubsection{Characterization of dissolved organic matter}

The aromaticity and humification of the organic species released during the ANC-BNC test was assessed using indexes derived from UV-VIS absorbance measurements. Figure 5.b shows that the values of SUVA measured at alkaline $\mathrm{pH}$ values were over three, indicating that the leached organic species exhibited a high level of humification (Chin et al., 1994). SUVA was found to increase strongly with increasing $\mathrm{pH}$, following in a proportional manner the increase of DOC release. This observation and the evolution of the aromaticity ratio, reaching $37 \%$ at $\mathrm{pH} 12.3$ (Figure 5.b), suggested that the organic species leached in this $\mathrm{pH}$ range were increasingly humified. On the contrary, under acidic conditions, the aromaticity ratio of the DOC was in general below $10 \%$, suggesting the release of poorly humified compounds. Chin et al. (1994) reported that low molecular weight microbial metabolites would generally exhibit an aromaticity index below $15 \%$.

The evolution of ratio $A_{1}$ in the leachates is shown in Fig. 5.b. Between $\mathrm{pH} 2$ and $6, \mathrm{~A}_{1}$ values were above 5, indicating a low level of humification. The ratio decreased at $\mathrm{pH}>6$, down to ca. 1 at $\mathrm{pH}$ around 8 to 11 revealing a strong aromaticity of the organic compounds released in this range of alkaline pHs.

\subsubsection{Relationships between DOC and trace metals leaching behaviors}

Sequential chemical extractions (Fig. 1.b) revealed that the trace metals most bound to $\mathrm{OM}$ were $\mathrm{Cu}$ and $\mathrm{Pb}$. However, it was also observed that significant proportions of the other metals (around 20\%) were associated to the organic matter. The leaching of OM may therefore strongly influence the respective leaching behavior of all trace metals studied here.

Fig. 6 compares the leaching profiles of the selected elements obtained in the present study from the organic sludge deposit to the profiles of the same elements collected from published studies conducted on bottom ash from municipal solid waste incineration (Gonzalez 
et al., 2014), which are mostly inorganic waste (only $2.1 \%$ of organic matter content). For all considered elements except $\mathrm{Cr}$, it can be seen that the extent of leaching at alkaline pHs was much stronger from the organic sludge deposits than from the inorganic waste, especially for copper. Lead was present in the sludge deposits at much lower concentrations than $\mathrm{Cu}$ and was therefore released at much smaller concentrations with only few data above the quantification limit (Fig. 4). However, Fig. 6 shows that the release of lead at alkaline pH was stronger from the organic sludge deposits than from the inorganic bottom ash (Fig. 6). The amplification of leaching under alkaline conditions was attributed to the association the considered elements to the particulate organic matter (POM) of the sludge deposit sample. Alkaline pHs induced a release of organic constituents from the POM (Davis, 1984; Lu \& Allen, 2002), probably through hydrolysis phenomena, resulting in the leaching of associated metals, particularly copper (Nelson et al., 2009). This conclusion was confirmed by the humified nature of organic species leached at high $\mathrm{pH}$ values, confirming conclusions from previously published studies (Hernandez et al., 2006; Plaza et al., 2006; Plaza et al., 2005). Qi et al. (2016) showed previously that the humification of organic matter increased its sorption capacity of copper. It was therefore concluded that the leaching of trace metals from the sludge deposits, especially copper, was influenced by their association with the organic fraction in the sludge deposits structure. 

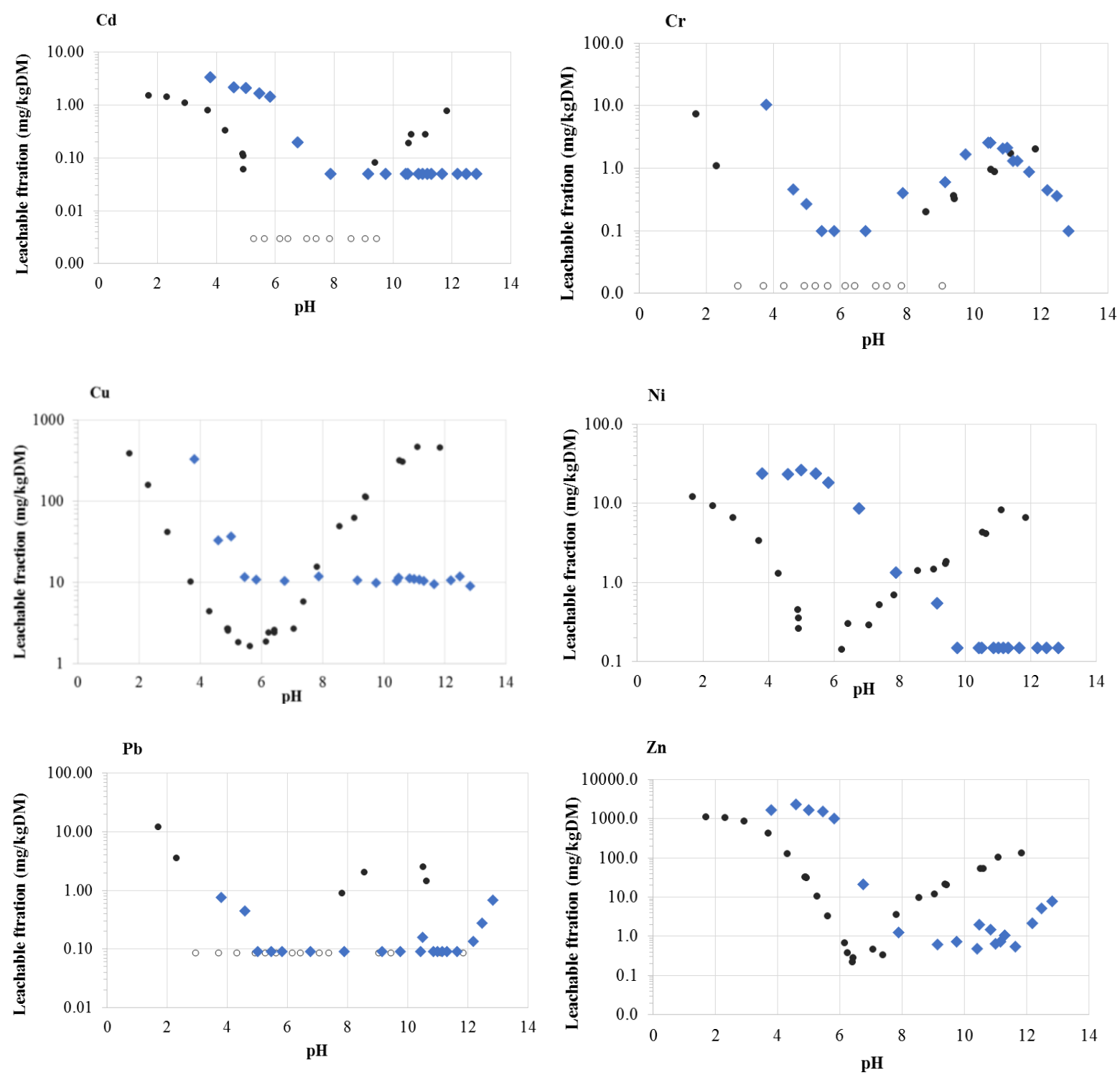

- Bottom ash (Gonzalez et al., 2014)

- Sludge deposit (this study)

Fig. 6. Leaching profiles of selected trace metals from bottom ash (blue dots, from Gonzalez et al., 2014) and sludge deposit (black dots, this study).

\section{Conclusions}

A representative sample of sludge deposits taken from an 8-year old French VFCW was used to investigate the leaching behavior of its major elements and a selection of trace metals. The physical properties and organic matter composition of the selected sample was previously shown to be representative of a typology of surface deposits from French VFCW of more than 2-3 years of age (Kania et al., 2019; Kania et al. 2018 a and b). The results obtained here firstly 
showed that only marginal proportions of the total contents in major elements and trace metals were leached from the surface deposits into the aqueous solution when the sample was contacted with water at the close-to-neutral $\mathrm{pH}$ obtained at thermodynamic equilibrium $(\mathrm{pH}$ 6.4). Acid and Base Neutralization Capacities tests inspired from waste leaching protocols proved to be relevant to assess the effects of $\mathrm{pH}$ on leaching. A $\mathrm{pH}$-dependent leaching profile was observed for all monitored elements. The metals exhibiting a strong leaching under alkaline $\mathrm{pH}$ were either amphoteric elements (such as $\mathrm{Zn}, \mathrm{Al}, \mathrm{Fe}$ ) and / or associated to organic matter within the sludge deposits. This was particularly the case for copper, which was released more extensively under alkaline than acidic conditions, following a similar $\mathrm{pH}$-dependent profile as the sludge organic matter itself. The leaching pattern of copper was explained by the fact that most of copper (more than $70 \%$ of its total content) was associated in the sample with organic matter as shown by sequential extractions of trace metals. The sequential extractions showed that the other trace metals were distributed in several fractions, including significant proportions associated to organic matter. Their leaching was therefore influenced in part by the leaching of organic ligands at alkaline pHs. The major elements were mostly found in the residual, stable fraction, and were therefore poorly leached either under acidic or alkaline conditions.

\section{Acknowledgments}

The authors wish to thank Nathalie Dumont and David Lebouil of DEEP for chemical analyses (ICP-AES), the LEHNA (Ion chromatography) and the SARM (Service of Analyses of Rocks and Minerals) for their contributions to chemical analyses. They also thank the French ANRT (National Agency for Technological Research) and the French company SCIRPE for their financial and scientific support. 


\section{References}

AFNOR, 2007. Norme NF EN 15169. Caractérisation des déchets - Détermination de la perte au feu des déchets, des boues et des sédiments (Determination of loss on ignition in waste, sludge and sediments).

Bruland, K.W. 1992. Complexation of cadmium by natural organic ligands in the central North Pacific. Limnology and Oceanography, 37(5), 1008-1017.

Caicedo, P.V., Rahman, K.Z., Kuschk, P., Blumberg, M., Paschke, A., Janzen, W., Schüürmann, G. 2015. Comparison of heavy metal content in two sludge drying reed beds of different age. Ecological Engineering, 74, 48-55.

Chatain, V., Sanchez, F., Bayard, R., Moszkowicz, P., Gourdon, R., 2005.Effect of experimentally induced reducing conditions on the mobility of arsenic from a mining soil. Journal of Hazardous Materials. 122, 119-128.

Chatain, V., Blanc, D., Borschneck, D., Delolme, C. 2013. Determining the experimental leachability of copper, lead, and zinc in a harbor sediment and modeling. Environmental science and pollution research international, 20(1), 66-74.

Chazarenc, F., Merlin, G. 2005. Influence of surface layer on hydrology and biology of gravel bed vertical flow constructed wetlands. Water science and technology, 15(n $\left.{ }^{\circ} 9\right), 91-97$.

Chen, M., Pang, L., Blanc, D., Gautier, M., Gourdon, R. and Mehu, J. Characterization of sewage sludge ash and technical and environmental evaluation for potential utilization as secondary raw materials in construction. In Proceedings of 3rd International Conference on Engineering for Waste and Biomass Valorisation, May 17-19, 2010, Beijing, China.

Chen, T., Zhou Z., Xu, S., Wang H., Lu W. 2015. Adsorption behavior comparison of trivalent and hexavalent chromium on biochar derived from municipal sludge. Bioresource Technology, 190, 388-394.

Chin, Y.-P., Alken, G., O'Loughlin, E. 1994. Molecular weight, polydispersity, and spectroscopic properties of aquatic humic substances. Environmental science \& technology, 28, 1853-1858.

Da Silva, I.S., Abate, G., Lichtig, J., Masini, J.C. 2002. Heavy metal distribution in recent sediments of the Tietê-Pinheiros river system in Sao Paulo state, Brazil. Applied geochemistry, $17,105-116$.

Davis, J.A. 1984. Complexation of trace metals by adsorbed natural organic matter. Geochimica et Cosmochimica Acta 48, 619-691.

Di Luca, G.A., Maine, M.A., Mufarrege, M.M., Hadad, H.R., Sánchez, G.C., Bonetto, C.A. 2011. Metal retention and distribution in the sediment of a constructed wetland for industrial wastewater treatment. Ecological Engineering, 37(9), 1267-1275.

Du, Y.J., Wei, M.L., Reddy, K.R., Liu, Z.P., Jin, F. 2014. Effect of acid rain pH on leaching behavior of cement stabilized lead-contaminated soil. Journal of hazardous materials, 271, 13140 .

Drapeau, C., Delolme, C., Chatain, V., Gautier, M., Blanc, D., Benzaazoua, M., Lassabatère, L. 2017. Spatial and Temporal Stability of Major and Trace Element Leaching in Urban Stormwater Sediments. Open Journal of Soil Science, 07(11), 347-365. 
Fang, W., Wei, Y., Liu, J. 2016. Comparative characterization of sewage sludge compost and soil: Heavy metal leaching characteristics. Journal of hazardous materials, 310, 1-10.

Fuentes, A., Lloréns, M., Sáez, J., Soler, A., Aguilar, M.I., Ortuño, J.F., Meseguer, V.F. 2004. Simple and sequential extractions of heavy metals from different sewage sludges. Chemosphere, 54(8), 1039-1047.

Gill, L.W., Ring, P., Casey, B., Higgins, N.M.P., Johnston, P.M. 2017. Long term heavy metal removal by a constructed wetland treating rainfall runoff from a motorway. The Science of the total environment, 601-602, 32-44.

Gonzalez, M.L., Blanc, D., de Brauer, C. Geochemical modeling of major and trace elements leaching behavior from MSWI bottom ash. In Proceedings of 5th International Conference on Engineering for Waste and Biomass Valorisation, August 25-28, 2014, Rio de Janeiro, Brazil.

Gonzalez, M.L., Blanc, D., de Brauer, C. 2017. Multi-Analytical Approach and Geochemical Modeling for Mineral Trace Element Speciation in MSWI Bottom-Ash. Waste and Biomass Valorization. 1-11.

Grybos, M., Davranche, M., Gruau, G., Petitjean, P., Pédrot, M. 2009. Increasing pH drives organic matter solubilization from wetland soils under reducing conditions. Geoderma, 154(12), 13-19.

Hernandez, D., Plaza, C., Senesi, N., Polo, A. 2006. Detection of copper(II) and zinc(II) binding to humic acids from pig slurry and amended soils by fluorescence spectroscopy. Environmental Pollution, 143(2), 212-20.

Jenne, E.A., 1968. Controls on $\mathrm{Mn}, \mathrm{Fe}, \mathrm{Co}, \mathrm{Ni} \mathrm{Cu}$ and $\mathrm{Zn}$ concentrations in soils and water: the significant role of hydrous $\mathrm{Mn}$ and Fe oxides. In: Gould, R.F. (Ed.), Advances in Chemistry Series. Trace Inorganics in Water, vol. 73. American Chemical Society Publications, Washington, DC, pp. 337-387.

Kania, M. (2018). Caractérisation des dépôts de surface des filtres plantés de roseaux à écoulement vertical. Rôle et évolution de la matière organique particulaire. Doctoral thesis ; INSA de Lyon, France ; June 1st, 2018, 265 pages

Kania, M. Gautier, M., Michel P. \& Gourdon, R. (2018a) Study of aggregation in surface sludge deposits from 14 French vertical flow constructed wetlands using particle size distribution and dynamic vapor sorption analyses. Water Science \& Technology ,77(1), 79-90. DOI: 10.2166/wst.2017.523.

Kania, M., Gautier, M., Michel P., Liu J., Li Z., James, P., Gourdon R. (2018b). Analytical indicators to characterize particulate organic matter evolutions in vertical flow constructed wetlands Science of the total environment, 622-623, 801-813.

Kania,M., Gautier,M., Imig, A., Michel, P., Gourdon, R., 2019. Comparative characterization of surface sludge deposits from fourteen French Vertical Flow Constructed Wetlands sewage treatment plants using biological, chemical and thermal indices. Science of the Total Environnent. 6 (647), 464-473.

Kim B., Gautier M., Michel P., Gourdon R. 2013. Physical-chemical characterization of sludge and granular materials from a vertical low constructed wetland for municipal wastewater treatment. Water Science \& Technology. 68(10), 2257-2262.

Kim, B., Gautier, M., Prost-Boucle, S., Molle, P., Michel, P., Gourdon, R. 2014. Performance evaluation of partially saturated vertical-flow constructed wetland with trickling filter and 
chemical precipitation for domestic and winery wastewaters treatment. Ecological Engineering, 71, 41-47.

Kim B., Gautier M., Rivard C., Sanglar C., Michel P., Gourdon R. 2015 Effect of aging on phosphorus speciation in surface deposit of a vertical flow constructed wetland. Environmental science \& technology. 49 (8), 4903-4910;

Kim, B., Gautier, M., Simidoff, A., Sanglar, C., Chatain, V., Michel, P., Gourdon, R. 2016. pH and Eh effects on phosphorus fate in constructed wetland's sludge surface deposit. Journal of environmental management, 183, 175-81.

Lachassagne, D. 2015. PhD Thesis. Devenir de micropolluants présents dans les boues d'épuration, du traitement à l'épandage agricole : Application aux micropolluants métalliques $(\mathrm{Cd}, \mathrm{Cu})$ et organiques (médicaments) issus du traitement biologique conventionnel d'effluents urbains ou hospitaliers (Becoming of micropollutants in sewage sludge, from treatment to agricultural application: Application to metallic $(\mathrm{Cd}, \mathrm{Cu})$ and organic micropollutants (drugs) resulting from the conventional biological treatment of urban or hospital effluents). in: Environment Sciences, University of Limoges. Limoges, France, pp. 269.Lu, Y., Allen, E.H. 2001. Partitioning of copper onto suspended particulate matter in river waters. The Science of the Total Environment 277, 119-132.

Lu, Y., Allen, H.E. 2002. Characterization of copper complexation with natural dissolved organic matter (DOM) - link to acidic moieties of DOM and competition by Ca and Mg. Water Research 36, 5083-5101.

Martin-Torre, M.C., Payan, M.C., Verbinnen, B., Coz, A., Ruiz, G., Vandecasteele, C., Viguri, J.R. 2015. Metal release from contaminated estuarine sediment under $\mathrm{pH}$ changes in the marine environment. Archives of environmental contamination and toxicology, 68(3), 577-87.

Matamoros, V., Nguyen, L.X., Arias, C.A., Nielsen, S., Laugen, M.M., Brix, H. 2012. Musk fragrances, DEHP and heavy metals in a 20 years old sludge treatment reed bed system. Water research, 46(12), 3889-96.

McBride, M., Blasiak, J. 1979. Zinc and copper solubility as a function of $\mathrm{pH}$ in an acid soil. Soil Science Society of America Journal, 43(5), pp. 866-870.

Mikutta, R., Kleber, M., Kaiser, K., Jahn, R. 2005. Review: Organic matter removal from soils using hydrogen peroxide, sodium hypochlorite, and disodium peroxodisulfate. Soil Science Society of America Journal, 69(1), 120-135.

Molle, P., Liénard, A., Boutin, C., Merlin, G., Iwema, A. 2004. Traitement des eaux usées domestiques par marais artificiels: etat de l'art et performances des filtres plantés de roseaux en France. Ingénieries (Special issue), 23 - 32.

Molle, P., Liénard, A., Grasmick, A., Iwema, A. 2005. How to treat raw sewage with constructed wetlands: An overview of the French systems. Water Science and technology $51\left(n^{\circ} 9\right), 11-21$.

Morvannou, A., Forquet, N., Michel, S., Troesch, S., Molle, P. 2015. Treatment performances of French constructed wetlands: results from a database collected over the last 30 years. Water science and technology, 71(9), 1333-9.

Nelson, S.S., Yonge, D.R., Barber, M.E. 2009. Effects of Road Salts on Heavy Metal Mobility in Two Eastern Washington Soils. Journal of environmental engineering, 135(7), 505-510. 
Nielsen, S. 2005. Sludge reed bed facilities: operation and problems. Water Science \& Technology, 51(9), 99-107.

Nielsen, S., Bruun, E.W. 2015. Sludge quality after 10-20 years of treatment in reed bed systems. Environmental science and pollution research international, 22(17), 12885-91.

Orlov, D.S. 1986. Electron absorption spectra of humic substances. in: Humus acids of soils, A.A. Balkema Editors. Rotterdam, pp. 126-178.

Peyronnard, O., Benzaazoua, M., Blanc, D., Moszkowicz, P. 2009. Study of mineralogy and leaching behavior of stabilized/solidified sludge using differential acid neutralization analysis. Cement and Concrete Research, 39(7), 600-609.

Plaza, C., Brunetti, G., Senesi, N., Polo, A. 2006. Molecular and quantitative analysis of metal ion binding to humic acids from sewage sludge and sludge-amended soils by fluorescence spectroscopy. Environmental science \& technology, 40, 917-923.

Plaza, C., D'Orazio, V., Senesi, N. 2005. Copper(II) complexation of humic acids from the first generation of EUROSOILS by total luminescence spectroscopy. Geoderma, 125(1-2), 177-186.

Qi, Y., Zhu, J., Fu, Q., Hu, H., Huang, Q., Violante, A. 2016. Sorption of Cu by organic matter from the decomposition of rice straw. Journal of Soils and Sediments, 16(9), 2203-2210.

Rutkowska, A., Pikuła, D. 2013. Effect of crop rotation and nitrogen fertilization on the quality and quantity of soil organic matter. Soil processes and current trends in quality assessment (Book), Chapter 9, 250 - 267.

Samourgiannidis, G., Matsi, T. 2013. Comparison of Two Sequential Extraction Methods and the DTPA Method for the Extraction of Micronutrients from Acidic Soils. Communications in Soil Science and Plant Analysis, 44(1-4), 38-49.

Sanusi, A., Wortham, H., Millet, M., Mirabel, P. 1996. Chemical composition of rainwater in Eastern France Atmospheric environment, 30, 59-71.

Tessier, A., Campbell, P.G.C., Bisson, M. 1979. Sequential extraction procedure for the speciation of particulate trace metals. Analytical chemistry, 51, 844-851.

Vriens, B., Voegelin, A., Hug, S.J., Kaegi, R., Winkel, L.H.E., Buser, A.M., Berg, M. 2017. Quantification of Element Fluxes in Wastewaters: A Nationwide Survey in Switzerland. Environmental science \& technology, 51(19), 10943-10953.

Weishaar, J.L., Aiken, G.R., Bergamaschi, B.A., Fram, M.S., Fujii, R., Mopper, K. 2003. Evaluation of specific ultraviolet absorbance as an indicator of the chemical composition and reactivity of dissolved organic carbon. Environmental science \& technology, 37, 4702-4708.

Wiśniowska, E., Włodarczyk-Makuła, M. 2018. The effect of selected acidic or alkaline chemical agents amendment on leachability of selected heavy metals from sewage sludge. Science of the Total Environment, 633(15), 463-469.

Yang, J., Chen, L., Liu, L.-Z., Shi, W.-L., Meng, X.-Z. 2014. Comprehensive risk assessment of heavy metals in lake sediment from public parks in Shanghai. Ecotoxicology and Environmental Safety, 102, 129-135.

Zbytniewski, R., Buszewski, B. 2005. Characterization of natural organic matter (NOM) derived from sewage sludge compost. Part 1: chemical and spectroscopic properties. Bioresource technology, 96(4), 471-478. 